\title{
The Acquisition Phenomenon of Null and Overt Subjects in the Early Speech of Arabic-Speaking Children
}

\author{
Fawaz Ali Ahmed Qasem * \\ (University of Bisha, Saudi Arabia)
}

\begin{abstract}
This paper examines the early acquisition of null subjects and overt subjects and how they are distributed and realized in the early speech of Arabic dialect-speaking children. ${ }^{(1)}$ The study accounts for the phenomenon of subjects by examining a longitudinal corpus of two children, Wala and Ibraheem, who were around two years old, speaking Yemeni Ibbi Arabic (YIA) dialect. The production and elicited production data collection methods were used in the study to collect the corpus during five months. The results of the study showed that null-subjects appear with a high proportion compared to the overt subjects. It was found that null subjects and overt subjects in the speech of Ibraheem and Wala had a similar distribution in the imperfective and the perfective, of which $86-87 \%$ are null subjects and $12-14 \%$ are overt subjects. The paper examined the widespread linguistic phenomenon of Null Subject Parameter acquisition, (Rizzi, 1982; Hyams, 1986, 1989) that is emergence of null subjects in line with overt subjects. The paper supports Hyam's (1982) argument on the acquisition of Null Subject Parameter where we can find children acquire null subjects early around 2 years of age. In contrast to non-null subject languages (like English), Null Subject Languages (NSLs) like Arabic happen to have null subjects appear more frequently and this is due to the rich inflectional morphology of NSLs.
\end{abstract}

Keywords: Null Subject Languages (NSLs), overt subject, Yemeni Ibbi Arabic (YIA), null subject

\section{Introduction}

The existence of null subjects in child data has brought interesting and controversial accounts in both null subject languages and non-null subject languages. The reason behind the high proportion of the null subjects in Null Subject Languages (NSLs) is the rich

\footnotetext{
* Dr. Fawaz Ali Ahmed Qasem: Assistant Professor, Department of English, University of Bisha, Saudi Arabia. E-mail: faqasem@ub.edu.sa, Fawazrajehbu@gmail.com.

(1) Acknowledgments: I am very grateful to Prof. Shruti Sircar, Prof. Abdualhfeed Al-Fakih and Dr. Fauzia Abdullah for their constant comments and support. Our sincere thanks and gratitude go to all the participants and children's families and all participants in the study. We are really grateful to all of them for their patience and support during data collection recordings.
} 


\section{The Acquisition Phenomenon of Null and Overt Subjects in the Early Speech of Arabic-Speaking Children}

inflectional morphology in languages like Italian, Spanish, and Catalan (See Rizzi, 1982, 1993/4; Chomsky, 1982; Hyams, 1986, 1989; Sans \& Gavarró, 2006), Hebrew (Borer, 1986, 1989), and Arabic (Qasem, 2014). The existence of null subjects in the speech of children learning non-null subject languages, such as English, French and German, has been reported. There is also a contingency between the occurrence of nonfinite verbs and null subjects in overt subject languages. Table 1 summarizes the results of spontaneous production studies of Flemish, German, French, Dutch and English, which shows that null subjects in the child versions of these languages tend to occur in root clauses with verbs that are morphologically marked as infinitive. Overt subjects, in contrast, tend to occur with finite verbs. Children used more null subjects in RIs than in finite clauses and it is noticed that the percentage of null subjects in root infinitives (RI) is consistent over time whereas the null subject use in finite clauses gradually decreases over time (Haegeman, 1996; Phillips, 1995).

Table 1. Overt and null subject occurrence in finite and nonfinite clauses

\begin{tabular}{|c|c|c|c|c|c|c|c|c|}
\hline \multirow[b]{2}{*}{ Language } & \multirow[b]{2}{*}{ Child } & \multicolumn{3}{|c|}{ Finite Verbs } & \multicolumn{3}{|c|}{ Non-finite Verbs } & \multirow{2}{*}{ Source } \\
\hline & & Overt & Null & Total & Overt & Null & Total & \\
\hline Flemish & Maarten $1 ; 1$ & $75 \%$ & $25 \%$ & 92 & $11 \%$ & $89 \%$ & 100 & Krämer, 1993 \\
\hline German & Simone $1 ; 8-4 ; 1$ & $80 \%$ & $20 \%$ & 3636 & $11 \%$ & $89 \%$ & 2477 & Behrens, 1993 \\
\hline German & Andreas 2;1 & $92 \%$ & $8 \%$ & 220 & $32 \%$ & $68 \%$ & 68 & Krämer, 1993 \\
\hline French ${ }^{*}$ & Nathalie $1 ; 9-2 ; 3$ & $70 \%$ & $30 \%$ & 299 & $27 \%$ & $73 \%$ & 180 & Krämer, 1993 \\
\hline French $^{*}$ & Philippe $2 ; 1-2 ; 6$ & $74 \%$ & $26 \%$ & 705 & $7 \%$ & $93 \%$ & 164 & Krämer, 1993 \\
\hline Ductch & Hein $2 ; 3-3 ; 1$ & $68 \%$ & $32 \%$ & 3768 & $15 \%$ & $85 \%$ & 721 & Haegeman, 1995 \\
\hline English & Eve $1 ; 6-2 ; 3$ & $90 \%$ & $10 \%$ & 86 & $89 \%$ & $11 \%$ & 155 & Phillips, 1995 \\
\hline English & Adam $2 ; 3-3 ; 0$ & $69 \%$ & $31 \%$ & 113 & $80 \%$ & $20 \%$ & 242 & Phillips, 1995 \\
\hline
\end{tabular}

${ }^{*}$ For French, only preverbal subjects were counted. （Adapted from Hoekstra \& Hyams, 1998:16)

Salustri and Hyams $(2003,2006)$ argued that imperatives in Italian have the same status as RIs in German and French. Imperatives like root infinitives do not (generally) carry 'finite' morphology. They also display similar modal meanings, and are eventive and much more frequent in child speech than in the respective child-directed speech.

Interestingly Table 2 also illustrates the comparison between null subject and non-null subject languages and their relationship with RTs. As seen in Table 2, RIs were not attested in YIA like in other null subject languages (Italian, Catalan, Spanish \& Hungarian) and the imperatives were used in more than $50 \%$ of contexts in early stages of language acquisition. The imperative use decreases with age, as was found in all languages, where the imperative operates as a root infinitive analogue.

The highly frequent use of imperative form in YIA is consistent with that in Italian, 
Catalan and Spanish Hungarian (Qasem \& Sircar, 2017). Similarly, there is a decrease in the use of the imperative form, which signals that finite forms increase with age. The imperative form is a non-finite form, since it is devoid of agreement in person. Qasem \& Sircar addressed the important issue in pro-drop languages which is the relationship between Root Infinitive (RI) analogue and null subjects, since subjects are consistently dropped both in finite and non-finite clauses.

Table 2. RI and Imperative use in null and non null subject languages

\begin{tabular}{|c|c|c|c|c|}
\hline & Languages & Age & RI & IMP \\
\hline \multirow{2}{*}{ (a) } & \multirow{2}{*}{ German } & {$[2 ; 0-2 ; 4]$} & $81 \%$ & $1.5 \%$ \\
\hline & & {$[2 ; 6-2 ; 7]$} & $61 \%$ & $6.5 \%$ \\
\hline \multirow{2}{*}{ (b) } & \multirow{2}{*}{ Dutch } & {$[1 ; 7-2 ; 1]$} & $70.6 \%$ & -- \\
\hline & & {$[2 ; 1-2 ; 6]$} & $20.1 \%$ & -- \\
\hline \multirow{2}{*}{ (c) } & \multirow{2}{*}{ Icelandic } & {$[1 ; 7-2 ; 1]$} & $65 \%$ & $1 \%$ \\
\hline & & {$[1 ; 8-2 ; 4]$} & $24.1 \%$ & -- \\
\hline \multirow{2}{*}{ (d) } & \multirow{2}{*}{ Italian } & {$[2 ; 0-2 ; 4]$} & $2 \%$ & $55.5 \%$ \\
\hline & & {$[2 ; 6-2 ; 7]$} & $7 \%$ & $34.4 \%$ \\
\hline \multirow{2}{*}{ (e) } & \multirow{2}{*}{ Catalan } & {$[1 ; 7-1 ; 8]$} & $0 \%$ & $41 \%$ \\
\hline & & {$[2 ; 4-3 ; 00]$} & $0 \%$ & $31 \%$ \\
\hline (f) & Spanish & {$[2 ; 1-2 ; 3]$} & $0 \%$ & $41 \%$ \\
\hline (g) & Hungarian & {$[2 ; 1-2 ; 5]$} & $1 \%$ & $21 \%$ \\
\hline \multirow{2}{*}{ (h) } & \multirow{2}{*}{ Yemeni Ibbi Arabic } & {$[2 ; 1-2 ; 2]$} & $0 \%$ & $61.2 \%$ \\
\hline & & {$[2 ; 5-2 ; 6]$} & $0 \%$ & $18.1 \%$ \\
\hline
\end{tabular}

In this study, we look at the emergence of the overt subject in a pro-drop language. Little work has been done to account for the interesting controversial and widespread issues existing in the literature of linguistics from child data in Arabic. Significant works in Kuwaiti Arabic (Aljenaie, 2000, 2010) and YIA (Qasem, 2014, 2019; Qasem \& Sircar, 2017) have addressed the issue of non-finiteness in Arabic and the emergence of functional categories, AGR and TNS in Arabic. Interesting work concerning Arabic-speaking children with Specific Language Impairment (SLI) has been carried out by Abdalla (2002) and Abdalla \& Crago (2008). Looking at the verb morphology on Arabic-speaking children with SLI specifically on children speaking urban Hijazi Arabic, they explored the tense and agreement marking in their spontaneous speech. The findings of their studies indicated that the Arabic-speaking participants with SLI had obvious problems in verb morphology. The use of imperatives as default substitutes for tensed forms appeared to be a specific feature with the absence of bare roots and infinitives. 


\section{The Acquisition Phenomenon of Null and Overt Subjects in the Early Speech of Arabic-Speaking Children}

However, this work attempts to account for the phenomenon of null subjects and overt subjects in YIA in child language to check how null subjects and overt subjects are realized in an Arabic with rich inflectional system and what lies behind the existence of the optionality of using null subjects and overt subjects in Arabic noticed in child language in this study or in the adult speech.

Table 3 interestingly shows the distribution of the null subjects and overt subjects in Spanish and Catalan. It is clear from the table that the percentage of null subjects is higher compared to overt subjects and it varies between $58.3 \%$ and $72.1 \%$ whereas the percentage of the overt subjects is lower and it is between $27.9 \%$ and $41.7 \%$. Similarly, the pattern is found in Arabic. ${ }^{\mathbb{1}}$

Table 3. Null and overt subjects in Spanish and Catalan

\begin{tabular}{c|c|c|c|c|c|c}
\hline \multirow{3}{*}{ Language } & \multirow{2}{*}{ Child } & \multicolumn{2}{|c|}{ Null subjects } & \multicolumn{2}{c|}{ Overt subjects } & \multirow{2}{*}{ Total sentence } \\
\cline { 3 - 6 } & & $\mathrm{n}$ & $\%$ & $\mathrm{~N}$ & $\%$ & \\
\hline \multirow{4}{*}{ Spanish } & Maria & 1027 & $66.5 \%$ & 518 & $33.5 \%$ & 1545 \\
\cline { 2 - 7 } & Emilio & 484 & $72.1 \%$ & 187 & $27.9 \%$ & 671 \\
\cline { 2 - 6 } & Juan & 119 & $58.3 \%$ & 85 & $41.7 \%$ & 204 \\
\cline { 2 - 7 } & Total & 1630 & $67.4 \%$ & 790 & $32.6 \%$ & 2420 \\
\hline \multirow{4}{*}{ Catalan } & Gisela & 337 & $68.8 \%$ & 153 & $31.2 \%$ & 492 \\
\cline { 2 - 7 } & Julia & 255 & $67.3 \%$ & 124 & $32.7 \%$ & 379 \\
\cline { 2 - 6 } & Pep & 576 & $67.5 \%$ & 277 & $32.5 \%$ & 853 \\
\cline { 2 - 6 } & Total & 1168 & $67.7 \%$ & 556 & $32.3 \%$ & 1724 \\
\hline
\end{tabular}

(Adapted from Bel's work (2003) extracted from CHILDES project (MacWhinney, 1995))

Interestingly, in many studies, it is shown that the distribution of null and overt subjects in null subject languages have close percentages where the proportion of null subject utterances is higher than that of overt subjects in both child speech and adult speech in languages like Catalan, Spanish, Italian and Arabic (see Casanova, 1999; Bel, 2003; Lorusso, et al, 2005; Casielles, et al, 2006; Sans \& Gavarró, 2006; Qasem, 2014; Al-Momani, 2015; Al-Shawashreh, 2016).

Many interesting crosslinguistic studies have been conducted to explore the realization and distribution of subjects, particularly in the pro-drop languages. Klepper-Pang (2003) looked at the acquisition of optional elements in the verbal clauses in Polish and one aspect of the study focused mainly on the distribution of subjects (null and overt) in the spontaneous data of three children ranged between 1;4 and 2;2 years old. The study also covered the distribution of overt subjects' type position (preverbal or postverbal) in Polish.

\footnotetext{
(1) More details of the null and overt subjects in Arabic will be covered in section four, the results.
} 
The findings show that overt subjects occur in the early speech of Polish children both preverbally and postverbally. It is found that pronominal subjects were used more frequently than NP subjects. Similar results were recorded for Caribbean and European Spanish (Villa-Garcia, 2011) and Catalan and Spanish, (Grinstead, 1998, 2000). VillaGarcia (2011) also investigated the acquisition of subjects in Caribbean and European Spanish. The study addressed the issue of distribution and position of preverbal and postverbal subjects. The data came from four children in the CHILDS project who speak European-Spanish varieties and a longitudinal data came from one girl, Ana, a speaker of Caribbean Spanish. It was found that preverbal and postverbal subjects are acquired simultaneously.

Crosslinguistic investigations have also been done on the distributions of subjects with respect to the verb classes in the language. Sans and Gavarró (2006) examined the subjects, null and overt, in the early speech of Catalan children. The study was based on the longitudinal corpora of three Catalan-speaking children and the productions of the adults interacting with them. The study attempted to find out whether there are systematic differences between child- and adult-Catalan with regards to the null subject phenomenon in Catalan and whether the various verb classes in the language have relations with the distribution of subjects (postverbal or preverbal position). The results showed that the child productions of null and overt subjects are equivalent to the adult forms in Catalan after the initial stage.

Arabic is an NSL with a rich inflectional system which allows subjects to drop or to appear overtly. It is interesting to look at the widespread issues in null and non-null subject languages, like the realization of subjects, which has not been reported much in Arabic. The primary aim of this work is to analyze the acquisition of null and overt subjects in the early speech of Arabic-speaking children. The study shows how overt subjects are distributed preverbally and postverbally and how both pronominal and nominal subjects are realized.

This paper is divided into five sections. Section 1 exposes the prevailing phenomenon in the children's data in many NSLs similar to Arabic and gives a summary of the relationship between null subjects and RIs in NSLs existing in literature such as the realization of null and overt subjects in the child speech of NSLs. Section 2 provides the status of the optionality (null and overt subjects) that exists in adult speech of Arabic. In section 3 we give a description of the children corpus used for this study. Section 4 highlights the results of data analysis of the corpus of the two children, Wala and Ibrahim. And section 5 concludes the findings of the study. 


\section{The Acquisition Phenomenon of Null and Overt Subjects in the Early Speech of Arabic-Speaking Children}

\section{Null and overt subjects in adult speech in Arabic}

Firstly, let us look at the linguistic properties of the adult speech of Arabic with a close reference to YIA, and with comparison to the Standard Arabic (SA) to get a clear understanding of what null and overt subjects look like and how they are distributed. Like many dialects of Arabic, YIA is a pro drop or null-subject-object language ${ }^{\circledR}$, i.e. the subject may be dropped if it can be recovered from the morphological information in the verbal inflections as in (1). Arabic, like Italian, is a consistent NSL as it has a rich agreement system, and the agreement features can be used to retrieve the subjects as stated by Holmberg, 2010 and Roberts \& Holmberg, 2010 ${ }^{2}$.

$\begin{array}{ll}\text { (1) The verb } & \text { The referent } \\ \text { a. katabu-k } & \text { write -1S } \\ \text { b. katab-na } & \text { write -1P } \\ \text { c. katab } & \text { write -3MS } \\ \text { d. katab-ah } & \text { write -3FS } \\ \text { e. katab-u } & \text { write -3MP } \\ \text { f. katab-ein } & \text { write -3MP }\end{array}$

In YIA, objects of finite clauses may also be dropped. The primary focus is not on objects, since object drop has little known implications for tense and agreement in YIA which is the main interest in the study. ${ }^{3}$

However, the subjects may appear when there is a need to disambiguate between two subjects in the present contexts. The subjects can occur both preverbally or postverbally. Consider the examples $(2 \mathrm{a})$ and $(2 \mathrm{~b})$ below.

$$
\begin{array}{ccc}
\text { (2) a. Ali yi-nuum } & \text { badri. } \\
\text { Ali 3.sleep.MS } & \text { early } \\
\text { 'Ali sleeps early.' } & \\
\text { b. yi-nuum Ali } & \text { badri. } \\
\text { 3.sleep.MS Ali } & \text { early } \\
\text { 'Ali sleeps early.' } &
\end{array}
$$

Spanish subjects, similarly, can be realized preverbally (3a) and postverbally (3b),

\footnotetext{
(1) The two linguistic terms pro drop and null subject have been used interchangeably, in the paper we consistently use pro drop, and non pro drop.

(2) Benmamoun, 1994; Eid, 1993; Mohammed, 1988; Farghaly, 1982; and Jelinek, 1983, 2002 proposed that null subjects exist when the predicates are marked for person feature and it is necessarily to the absence of null subjects in the sentences.

(3) Objects in Arabic do not show agreement with verb, as shown in (a) Ahmed katab qiSSah. (Ahmed-M write-Past-3MS story-F, 'He wrote a story.') and (b) Sundus katabah kitaab (Sundus-F write-PERF.3FS book-M, 'Sundus wrote a book.'). The object in (a) is qiSSah 'story (F)', does not show agreement with the verb, which inflects for the masculine. The object in (b) is kitaab 'book (M)', does not show agreement with the verb which inflect for feminine.
} 
(Villa-Garcia, 2011).

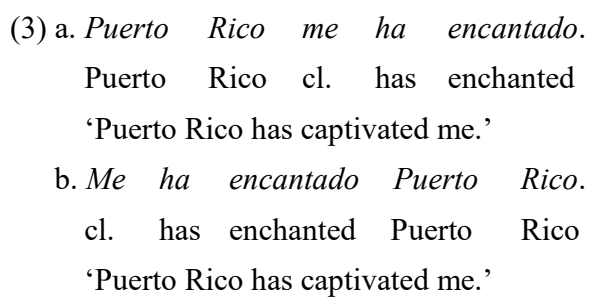

As in pro-drop language, word order in Arabic and many dialects of Arabic is flexible. Though there are various word orders, ${ }^{(1)}$ we focus on two main word orders in this discussion. The first word order includes the subject realized in preverbal position as subject-verb-object (SVO) as in example (4a). In the second word order the subject can be realized in postverbal position as verb-subject-object (VSO) as in example (4b). In the second word order, the subject can be in the postverbal position even when dropped as in $(4 \mathrm{c})$.

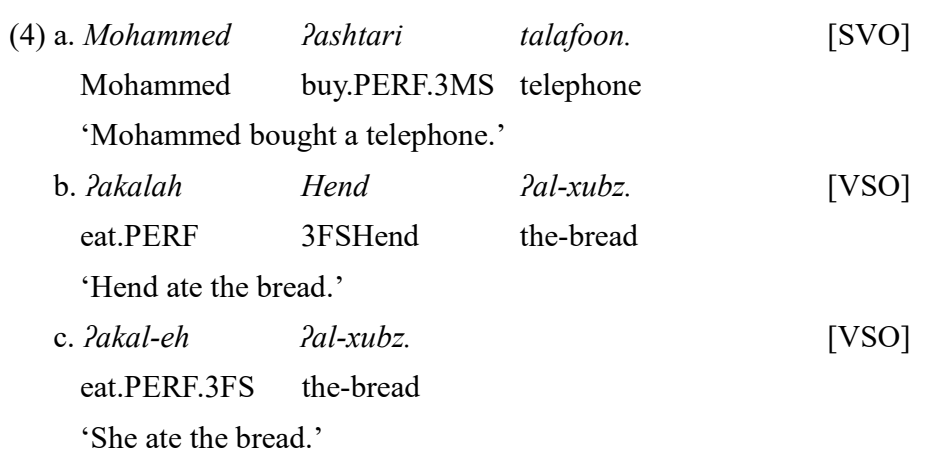

YIA has subject-verb-object (SVO) (5a) and verb-subject-object (VSO) (5b) word orders; VSO is treated as the unmarked order as it is used more frequently in different contexts.

$\begin{array}{llll}\text { (5) a. Ali shaat? } & \text { al-kurah. } & \\ \text { Ali kick.PERF.3MS } & \text { the-ball } & \\ \text { 'Ali kicked the ball.' } & & \\ \text { b. baaS Sammi } & \text { ParTHiyah } & \text { Pams. } \\ \text { sell.PERF.3MS uncle-my } & \text { land } & \text { yesterday } \\ \text { 'My uncle sold land last week.' } & & \end{array}$

In this part, we present the subject-verb agreement system in YIA in comparison to the subject-verb-agreement system in the Modern Standard Arabic (MSA) to bring out the differences.

Standard Arabic has two types of agreements, full and partial, with respect to two

\footnotetext{
(1) For more details about word order in Arabic cf. Al-Asbahi, 2001.
} 


\section{The Acquisition Phenomenon of Null and Overt Subjects in the Early Speech of Arabic-Speaking Children}

dominate word order SVO and VSO respectively. In SVO, there is full agreement and the subject and the verb agree in person, number, and gender as in (6a); and in VSO, there is partial agreement: subject and verb agree in person and gender, and but not number, as in (6b).

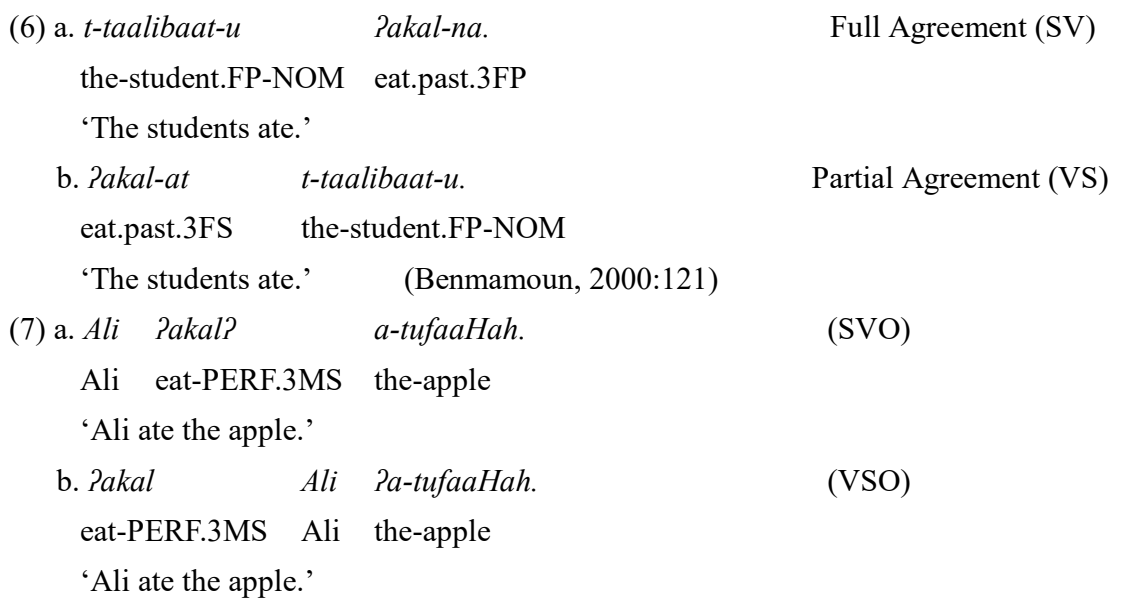

Unlike MSA, YIA always has full-subject agreement whether the word order is SV or VS, as is shown in example (7a) and (7b). Interestingly, the verb forms are irrespective of the change of the word order. Notice that the verbal overt marker $-u$ of the nominative case in (6a) and (6b) which is realized for third masculine plural, does not change in SV and VS word orders. Similarly, in another dialect of Arabic, Jordanian Arabic (JA), the agreement is full and it acts in the same way as in YIA. Notice that there is no change in the lexical Noun Phrase (NP) in the sentences in (8) (Al-Momani, 2015), unlike MSA.

$$
\begin{aligned}
& \text { (8) a. Naam l-walad. } \\
& \text { Slept the-boy } \\
& \text { 'The boy slept.' } \\
& \text { b. l-walad naam. } \\
& \text { the-boy slept } \\
& \text { 'The boy slept.' }
\end{aligned}
$$

Studies have tried to account for the position of overt subject (preverbally or postverbally) in languages with multiple word orders. Also, the interest has been put in what type of subjects (nominal or pronominal) occurs in what positions in such languages. In this section, we look at the distribution of overt subject in YIA adult language. As we have shown earlier, in YIA subjects can occur both preverbally and postverbally and in both word orders there is full agreement. However, there is common consensus that pronominal subjects occur only preverbally, and cannot occur postverbally (Fassi-Fehri, 1993; Harbert \& Bahloul, 2002). For them in MSA, which has partial agreement in VSO 


\section{Fawaz, Ali Ahmed Qasem}

order, subjects in the postverbal position are possible only when they are lexical DPs as in (9), where the verb does not have to agree in number with the pronoun.
(9) Xarag-uu hum wa Sami.
Left-3MP/left-3MS they and Sami
'They and Sami left.'
(Harbert \& Bahloul, 2002)

Soltan (2007) and Saeed (2011) have also shown that pronominal subjects can occur postverbally in MSA in what is called a 'conjunction phase' as in (10).
(10) haDar-uи hum wa Paabaa-u-hum.
came.3MP they and father-nom-their
'They and their father came.'

The pronominal subjects occurring in the post verbal positions need not be conjugated as mentioned earlier. Al-Sharafi (2014) gave evidence (11a-b) from MSA that pronominal elements can be realized postverbally.

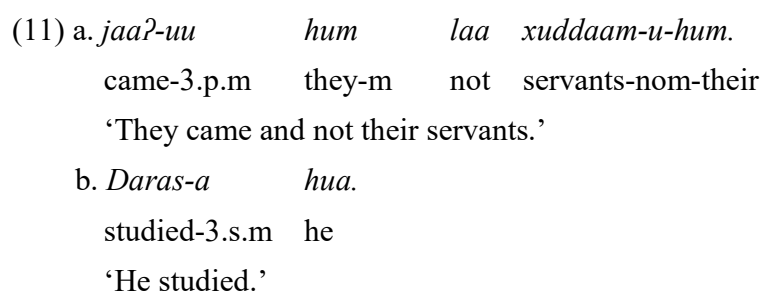

(Fassi-Fehri, 1993:113)

In YIA, subjects can occur preverbally as in (12a-b) and (13a-b) and postverbally as either pronominal subjects or nominal subjects.

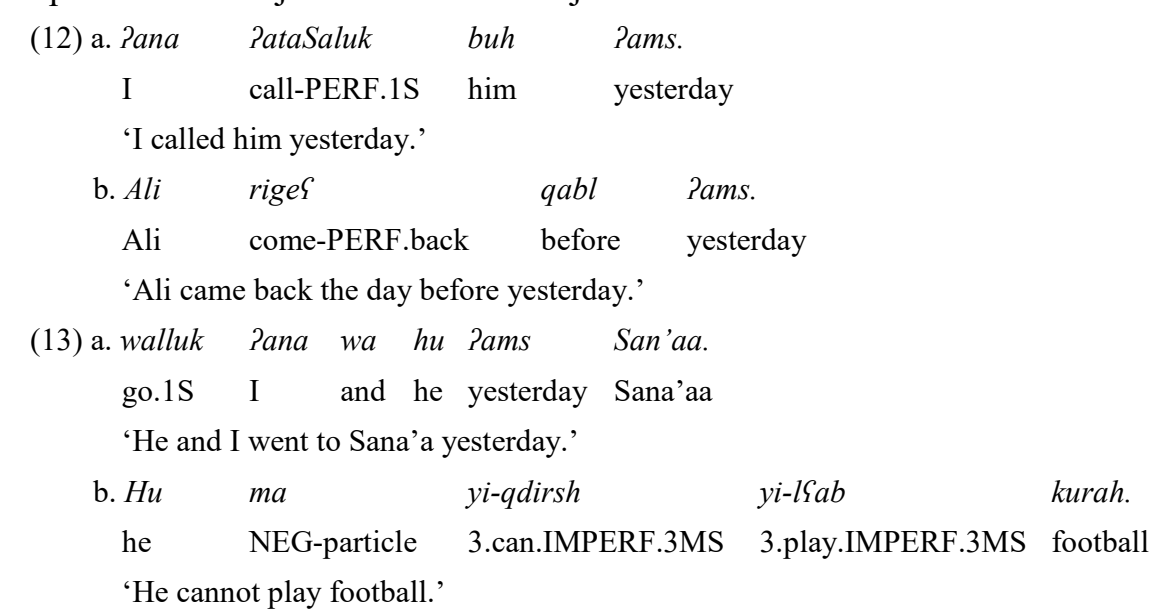

Subjects ${ }^{\mathbb{1}}$ in YIA can be preverbal or postverbal freely, be them nominals or

\footnotetext{
(1) The subjects in SA in preverbal position have been considered as topics in the traditional linguistics and in many recent studies. Many interesting studies have looked at this phenomenon of subjects and topics' positions. (Benmamoun, 1994; Soltan, 2007; Aoun et al., 2010; Al-Balushi, 2011; Saeed, 2011)
} 


\section{The Acquisition Phenomenon of Null and Overt Subjects in the Early Speech of Arabic-Speaking Children}

pronominals. Examples from Tihami Yemeni Arabic (TYA) also show that pronominals (14a-b) and nominals (14c) can be postverbal or preverbal in (14d) and (14e).
(14) a. riHtu ?ana ?amsu:q.
go.PERF.1S I the market
'I went to the market.'
b. waTTan hi PamGada
cook.PERF.3MS she the lunch
'She cooked the lunch.'
c. qaabal-un PimTalab Pamidiir.
meet.PERF.3MP the-students the headmaster
'The students met the headmaster.'
d. $h u$ raged badri.
he sleep.PERF.3MS early
'He slept early.'
e. PimTaaleb qaabal-un Pamidiir.
the-student meet.PERF.3MP the-headmaster
'The student met the headmaster.'

More data on TYA and on this regard can be checked in Al-Sharafi (2014). Similar to YIA, Kwaiti Arabic (KA) dialect shows the linguistic realization of subjects in different positions, which can be preverbal (15a), null (15b) or postverbal (15c) (Aljenaie, 2010).

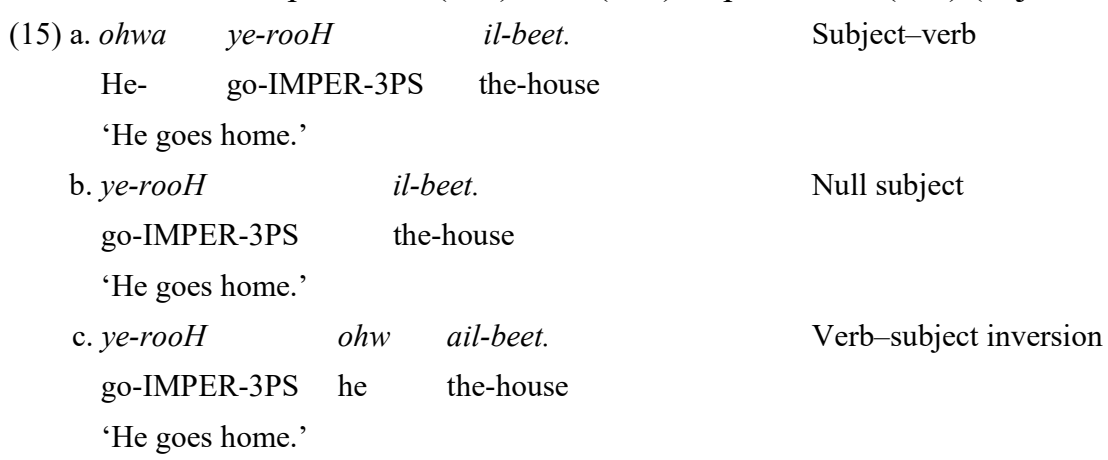

There is something interesting in the overt subject agreement in YIA. When there are two overt conjugated subjects, the agreement marked in the verb follows the first lexical subject - if it is masculine, the marker will be masculine, and if the first lexical subject is feminine, the marker will be feminine. Consider the examples (16a) and (16b).

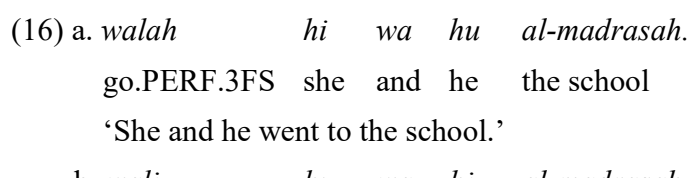




\section{Fawaz Ali Ahmed Qasem}

go.PERF.3M She and she the school

'He and she went to the school.'

Though overt subjects are allowed in Arabic dialects, they are used less often due to the fact that speakers of Arabic prefer null subjects than overt subjects. Al-Momani (2015) interestingly examined the phenomenon of overt and null subjects in JA. Based on the natural speech of adults speaking JA, he checked the role of morphology in allowing and motivating sentence in JA to be formed with or without subjects for different periods and how both overt and null subject pronouns are distributed and to what extent the optionality works with such distribution.

\section{Data analysis method}

The data examined for this study came from mono-lingual Arabic speakers, Ibraheem (2;1 to $2 ; 5)$ and Wala (2;6 to $2 ; 10)$, which was collected longitudinally in five months. Two methods of data collection were used. The natural production data and informal elicited production data were used in the video recording sessions. The speech data were coded manually to find occurrences of subjects in YIA. In counting uses of the constructions (null/overt; pronominal/nominal subjects; preverbal/ postverbal subjects), all imitations of adult utterances, repetition of the same utterances in the context, and formatic expressions were discarded. All utterances containing overt subjects were counted, categorized and tabulated. The relevant utterances were coded for subject type (pronominal/ nominal) and position (SV, VS). In order to check for acquisition of the pertinent use, the age of emergence of the target utterances was noted down.

\section{Results}

The section presents the realization of subjects in the speech corpora of Ibraheem and Wala. Arabic, as stated earlier, is a pro-drop language: subjects are optional in finite clauses and may not be realized phonologically where the context is supportive. English-speaking children were found to drop subjects from finite clauses even though it is not allowed. This phenomenon in English and other non-pro-drop languages is referred to as 'null subject in child language' (see Rizzi, 1982; Hyams, 2005; Hyams \& Wexler, 1993) for a detailed discussion).

The analysis of subjects in child YIA provides evidence that (1) YIA-speaking children optionally use/drop subjects in finite clauses as early as 2;1 and show knowledge of the null-subject parameter. (2) Both types of overt subjects, nominal subjects (which can be single words or phrases), and pronominal subjects are used simultaneously from the beginning. (3) These subjects are used both preverbally and postverbally though preverbal subjects are used more often than postverbal subjects. 


\section{The Acquisition Phenomenon of Null and Overt Subjects in the Early Speech of Arabic-Speaking Children}

All utterances in Ibraheem and Wala corpora were analyzed for the presence and the absence of overt subjects. Imperative constructions were excluded from the analysis since subjects are usually dropped in such constructions. The subjects were analyzed for the type and position in finite clauses. YIA children knew that they were learning a pro-drop language and they used more null subjects, though the corpora showed the use of null and overt subject around the same time. We also found that there was no difference between null and overt subject in tense and agreement no matter in what context they occur.

\subsection{Distribution of null and overt subject in child speech}

Figures 1 and 2 present the distribution of null and overt subject in Ibraheem's and Wala's speech respectively (in percentage).
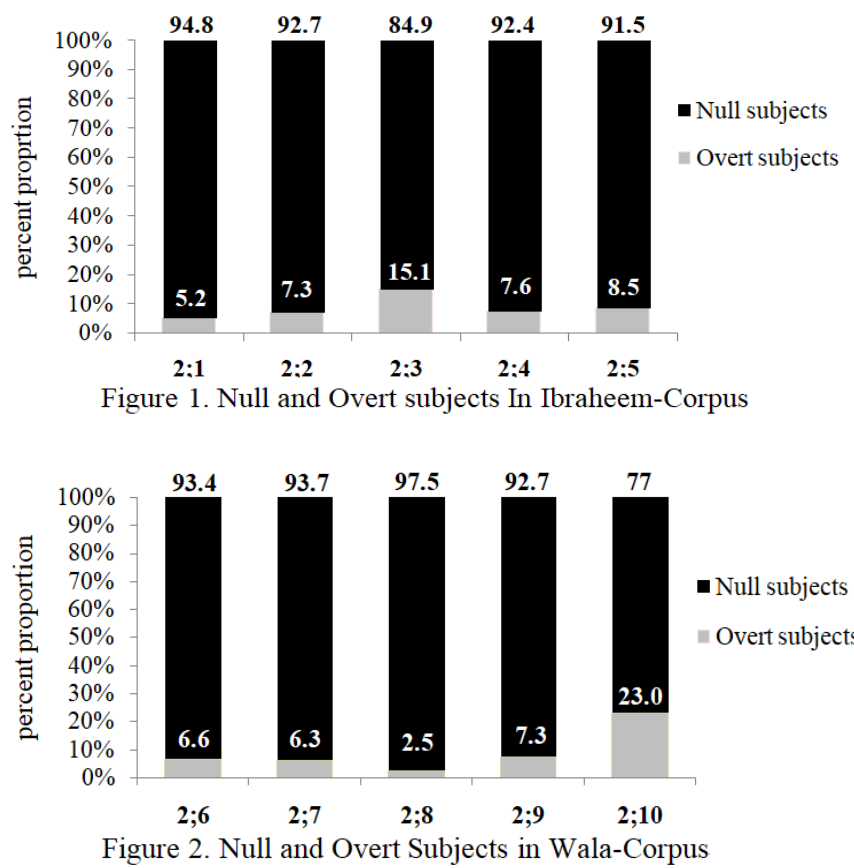

In both Ibraheem's and Wala's speech, null subjects were used in $90 \%$ of the cases, while overt subjects were in the range of $5-15 \%$. Between $2 ; 1$ and 2;9, and no noticeable difference in the use of overt subject was found. At 2;10, the overt subject use increased to $23 \%$ which was a sharp increase compared to that at $2 ; 9(7.3 \%)$. However, this piece of evidence cannot be conclusively used to argue that the use of overt subjects increase with age and proficiency, since we do not have speech data after 2;10. Even though the use of overt subjects was significantly lower than the use of null subjects, it is clear that they were nevertheless used from the earliest ages, alongside null subjects. This can be used to support the fact that children know that subjects were optional in YIA. 
The second evidence to show that children know that YIA is a pro-drop language is that they used the null and overt subjects in similar syntactic contexts, i.e. there were no distributional differences. Figures 3 and 4 present the distribution of the overt subjects in the imperfective and perfective constructions by Ibraheem and Wala respectively in percentage.

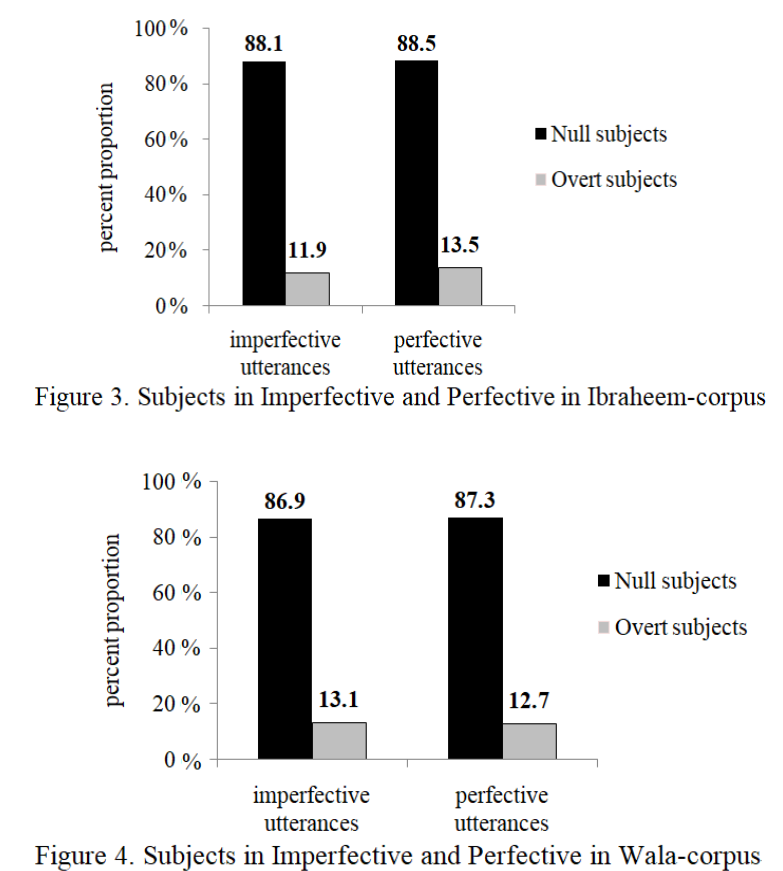

Null subjects and overt subjects in the speech of Ibraheem and Wala had similar distribution in the imperfective and the perfective, which was $86.9-87.3 \%$ null subjects versus $12.7-13.1 \%$ overt subjects.

\subsection{Types of overt subject}

Given the surprisingly low percentage of child utterances with overt subjects, it seems worthwhile to investigate the type of subjects involved. As is mentioned earlier, the data evaluation scheme contains one variable that specifies an overt subject with respect to its lexical content. We analyzed two types of overt subjects: Noun or NP, and personal pronoun or other pronouns (e.g. demonstrative pronouns). As we were particularly interested in the general issue of the clausal architecture and the presence of functional categories in early child grammar, the occurrence of personal (subject) pronouns was of special interest to us. Table 4 shows the distribution of the type of overt subjects in Ibraheem's and Wala's speech respectively.

Looking at the entire corpus of Ibraheem and Wala of overt subjects, NP subjects and 


\section{The Acquisition Phenomenon of Null and Overt Subjects in the Early Speech of Arabic-Speaking Children}

pronominal subjects were found to be used in the early speech of both children, Ibraheem and Wala, at the same time and both types were almost evenly distributed. However, Wala used more pronominal subjects (56.9\%) than full NPs (43.1\%) whereas Ibraheem used NPs $(50.5 \%)$ more than pronominal subjects $(49.5 \%)$. This is opposite to the distribution of subjects in Polish where pronominal subjects are used more frequently than nominal subjects (Klepper-Pang, 2003).

Table 4. Distribution of types of overt subject

\begin{tabular}{l|c|c|c}
\hline Child & Age & Nominal subject & Pronominal subject \\
\hline \multirow{5}{*}{ Ibraheem } & $2 ; 1$ & $50 \%$ & $50 \%$ \\
\cline { 2 - 4 } & $2 ; 2$ & $81.8 \%$ & $18.2 \%$ \\
\cline { 2 - 4 } & $2 ; 3$ & $44 \%$ & $56 \%$ \\
\cline { 2 - 4 } & $2 ; 4$ & $69.2 \%$ & $30.8 \%$ \\
\cline { 2 - 4 } & $2 ; 5$ & $25 \%$ & $75 \%$ \\
\hline \multirow{5}{*}{ Wala } & $2 ; 6$ & $18.2 \%$ & $81.8 \%$ \\
\cline { 2 - 4 } & $2 ; 7$ & $37.5 \%$ & $62.5 \%$ \\
\cline { 2 - 4 } & $2 ; 8$ & $0 \%$ & $100 \%$ \\
\cline { 2 - 4 } & $2 ; 9$ & $35.7 \%$ & $64.3 \%$ \\
\cline { 2 - 4 } & $2 ; 10$ & $65.5 \%$ & $34.5 \%$ \\
\hline
\end{tabular}

Among pronominal subjects the most frequent pronouns were personal pronouns, coming close to $90 \%$ of the total pronominal subjects. Apart from the first person, as in Ibraheem's and Wala's data, they usually displaced some other pronominals with determiners. The third masculine singular and third masculine plural are used respectively. No use of 'they' 'we' has been attested in either the speech of Ibraheem or that of Wala.

\subsection{Position of overt subject}

Table 5 presents the percentage of overt subjects in preverbal and postverbal positions in the speech of Ibraheem and Wala respectively.

Table 5. Distribution of pre- and postverbal subjects

\begin{tabular}{c|c|c|l|c|c}
\hline \multicolumn{3}{c|}{ Ibraheem-corpus } & \multicolumn{3}{c}{ Wala-corpus } \\
\hline Age & Preverbal subject & Postverbal subject & Age & Preverbal subject & Postverbal subject \\
\hline $2 ; 1$ & $83.4 \%$ & $16.6 \%$ & $2 ; 6$ & $81.8 \%$ & $18.2 \%$ \\
\hline $2 ; 2$ & $100 \%$ & $0 \%$ & $2 ; 7$ & $66.7 \%$ & $33.3 \%$ \\
\hline $2 ; 3$ & $96 \%$ & $4 \%$ & $2 ; 8$ & $100 \%$ & $0 \%$ \\
\hline $2 ; 4$ & $92.3 \%$ & $7.7 \%$ & $2 ; 9$ & $85.7 \%$ & $14.3 \%$ \\
\hline $2 ; 5$ & $100 \%$ & $0 \%$ & $2 ; 10$ & $55.2 \%$ & $44.8 \%$ \\
\hline
\end{tabular}


It is clear that preverbal subjects are preferred by children than postverbal subjects.

\subsubsection{Time of acquisition of preverbal and postverbal subject}

The first clear uses of preverbal (17a-b) and postverbal subjects (18a-b) are shown below for preverbal nominal and pronominal subject).

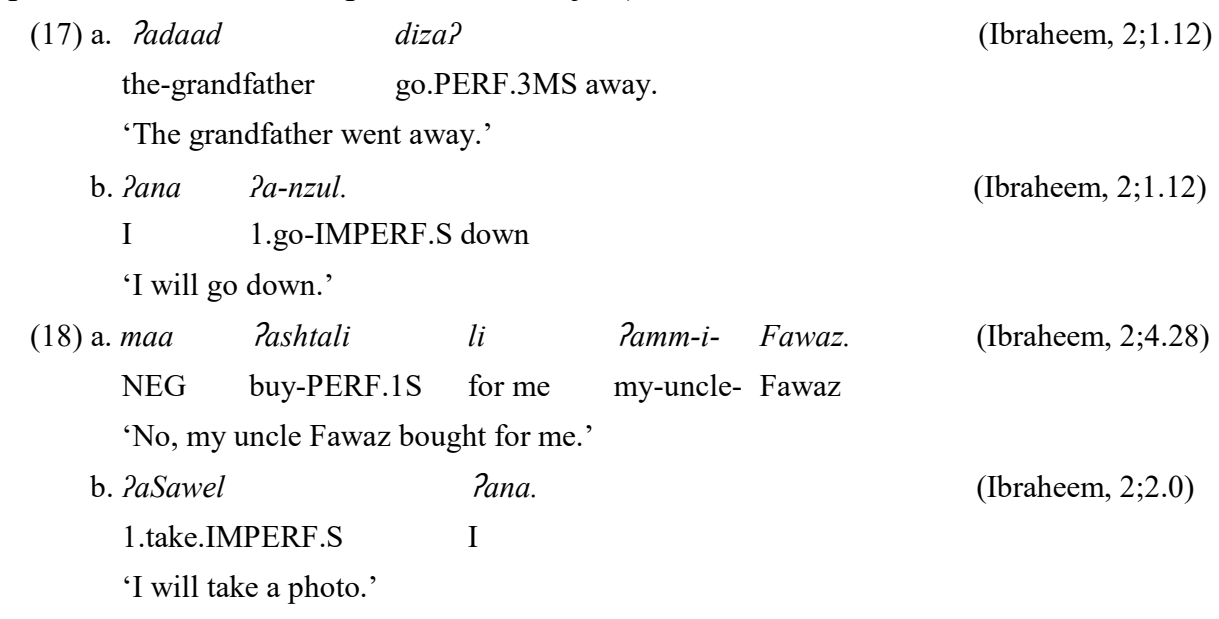

In the speech of Ibraheem, preverbal subjects, either nominals or pronominals, emerged early in the first month at $2 ; 1$ whereas the postverbal subjects emerged in different periods, the postverbal nominal subjects at 2;4,28 and postverbal pronominal subject at 2;2.

\subsubsection{Frequency of pre- and postverbal subject}

Tables 6 and 7 present the distribution of preverbal and postverbal subjects, for different types of subjects (nominal, pronominal, and determiner subjects) in Ibraheem and Wala respectively. This is to show which type of subjects is used more frequently and in which position they are used, preverbally or postverbally.

Table 6. Distribution of types of overt subjects in the Ibraheem-corpus

\begin{tabular}{c|c|c|c|c|c|c}
\hline \multirow{2}{*}{ Age } & \multicolumn{2}{|c|}{ Nominal subjects } & \multicolumn{2}{c|}{ Pronominal subjects } & \multicolumn{2}{c}{ Determiners } \\
\cline { 2 - 7 } & Preverbal & Postverbal & Preverbal & Postverbal & Preverbal & Postverbal \\
\hline $2 ; 1$ & 3 & 0 & 2 & 1 & 0 & 0 \\
\hline $2 ; 2$ & 9 & 0 & 1 & 0 & 1 & 0 \\
\hline $2 ; 3$ & 11 & 0 & 11 & 1 & 2 & 0 \\
\hline $2 ; 4$ & 9 & 0 & 3 & 1 & 0 & 0 \\
\hline $2 ; 5$ & 4 & 0 & 12 & 0 & 0 & 0 \\
\hline
\end{tabular}

In Ibraheem's speech, only 3 pronominal subjects occurred postverbally; nominals and determiners were never used, but pronominals had 29 preverbal subjects as well. However, in the speech of the older child, both nominals (16) and pronominals (3) were used postverbally. Interestingly, two findings can be drawn as follows: (i) Postverbal and 


\section{The Acquisition Phenomenon of Null and Overt Subjects in the Early Speech of Arabic-Speaking Children}

preverbal subjects were used at the same time. (ii) Postverbal subjects in the younger child's speech were used only with pronominal subjects, and were later extended to nominal subjects as seen in the older child, Wala.

Table 7. Distribution of types of overt subjects in the Wala-corpus

\begin{tabular}{c|c|c|c|c|c|c}
\hline \multirow{2}{*}{ Age } & \multicolumn{2}{|c|}{ Nominal subjects } & \multicolumn{2}{c|}{ Pronominal subjects } & \multicolumn{2}{c}{ Determiners } \\
\cline { 2 - 7 } & Preverbal & Postverbal & Preverbal & Postverbal & Preverbal & Postverbal \\
\hline $2 ; 6$ & 1 & 1 & 6 & 1 & 2 & 0 \\
\hline $2 ; 7$ & 2 & 1 & 4 & 1 & 0 & 0 \\
\hline $2 ; 8$ & 0 & 0 & 4 & 0 & 0 & 0 \\
\hline $2 ; 9$ & 3 & 2 & 7 & 0 & 2 & 0 \\
\hline $2 ; 10$ & 7 & 12 & 9 & 1 & 0 & 0 \\
\hline
\end{tabular}

\subsection{Distribution of types of semantic subject}

Here, we look at the distribution of the semantic types of subjects (with respect to person, number and gender) in the data of Ibraheem and Wala. Table 8 and Table 9 give a distribution of the semantic types of subjects in the utterances of Ibraheem and Wala.

Table 8. Distribution of the types of semantic subjects in the Ibraheem-corpus

\begin{tabular}{c|c|c|c|c|c|c}
\hline Age & $3 \mathrm{MS}$ & $3 \mathrm{FS}$ & $3 \mathrm{MP}$ & $1 \mathrm{~S}$ & $2 \mathrm{MS}$ & $2 \mathrm{FS}$ \\
\hline $2 ; 1$ & 2 & 1 & - & 3 & - & - \\
\hline $2 ; 2$ & 7 & 3 & - & 1 & - & - \\
\hline $2 ; 3$ & 11 & 3 & 1 & 11 & - & - \\
\hline $2 ; 4$ & 6 & 2 & - & 4 & - & - \\
\hline $2 ; 5$ & 2 & 2 & - & 11 & 1 & - \\
\hline Total & 28 & 11 & 1 & 30 & 1 & 0 \\
\hline
\end{tabular}

Table 9. Distribution of type of semantic subjects in the Wala-corpus

\begin{tabular}{c|c|c|c|c|c|c}
\hline Age & $3 \mathrm{MS}$ & $3 \mathrm{FS}$ & $3 \mathrm{MP}$ & $1 \mathrm{~S}$ & $2 \mathrm{MS}$ & $2 \mathrm{FS}$ \\
\hline $2 ; 6$ & 2 & 2 & - & 7 & - & - \\
\hline $2 ; 7$ & 2 & - & - & 5 & 1 & - \\
\hline $2 ; 8$ & - & - & - & 4 & - & - \\
\hline $2 ; 9$ & 6 & - & 1 & 7 & - & - \\
\hline $2 ; 10$ & 11 & 8 & - & 10 & - & - \\
\hline Total & 21 & 10 & 1 & 33 & 1 & 0 \\
\hline
\end{tabular}

Tables 8 and Table 9 show that third person singular and firstperson singular were used more often, and they appeared early at the age of 2;1. Singular pronouns emerged early and 
were used more frequently than plural pronouns. Second person pronouns were very rarely used and also appeared late at the age 2;5. Though the person, number and gender features on pronouns are lexically determined, a parallel is found between the semantic agreement in pronouns and the syntactic agreement on verbs.

\section{Conclusion}

From the results and as far as the distribution of overt vs. null subjects is concerned, the YIA data showed a low frequency of overt subjects, which is not surprising given the status of YIA as a null subject language. This approves that the null-subject parameter is acquired early in Arabic and this is due to the rich morphological system exists in many Arabic varieties and other languages as proposed by Rizzi, 1982; Chomsky, 1982; Hyams, 1986 that there is a relationship between the rich inflectional system and the empty categories.

We can conclude that the speech of Ibraheem showed that he had set the null-subject parameter by 2;1. It was also found that null subjects were used more often than overt subjects. Ibraheem had null subjects around $85-95 \%$ of his utterances and Wala had $77-97 \%$. In comparison, the use of overt subjects was 5-15\% in Ibraheem's corpus and $2-23 \%$ in Wala's. Note that Wala is an older child and therefore tended to use more overt subjects. We also found that the use of overt subjects increased with age. Nominal subjects and pronominal subjects co-occurred with comparable accuracy. Subjects occurred both preverbally and postverbally though preverbal subjects were used more frequently than postverbal subjects. Postverbal subjects initially occurred, particularly in the younger child's speech, only when the subject was pronominal and not when it was with a nominal and a determiner. For Wala, both nominal and pronominal subjects were used postverbally. In addition, overt subjects were more often used with first person, followed by the third person singular masculine subjects. The emergence of plural and feminine subjects showed a developmental delay, showing a general cognitive delay in the acquisition of number and gender. With regards to the distribution of the two types of overt subjects and the position of overt subjects, similar results have been found cross-linguistically in pro-drop languages. Acquisition data from Polish, for instance, showed the presence of overt subjects (NPs and pronominal) in the early speech of Polish children and they appear both preverbally and postverbally (Klepper-Pang, 2003).

\begin{tabular}{llll}
\multicolumn{2}{l}{ Abbreviations } & & \\
1S & first person singular & 3FP & third person feminine plural \\
1P & first person plural & 3FS & third person feminine singular \\
2FP & second person feminine plural & 3MP & third person masculine plural \\
2FS & second person feminine singular & 3MS & third person masculine singular \\
2MP & second person masculine plural & Agr & agreement \\
2MS & second person masculine singular & JA & Jordanian Arabic
\end{tabular}




\section{The Acquisition Phenomenon of Null and Overt Subjects in the Early Speech of Arabic-Speaking Children}

MLU

MSA

NSLs

RI mean length of utterances modern standard Arabic null subject languages root infinitive
SVO

TNS

VSO

YIA subject-verb-object

tense

verb-subject-object

Yemeni Ibbi Arabic

\section{References}

Abdalla, F. 2002. Specific Language Impairment in Arabic-speaking Children: Deficits in morphosyntax [D]. Ph.D. Dissertation, Canada: McGill University.

Abdalla, F. \& M. Crago. 2008. Verb Morphology Deficits in Arabic-speaking Children with Specific Language Impairment [J]. Applied Psycholinguistics, 29(2):315-340.

Al-Asbahi, K. 2001. Agreement and Word Order in English and Yemeni Arabic [D]. Ph.D. Dissertation, Hyderabad: English and Foreign Languages University.

Al-Balushi, R. 2011. Case in Standard Arabic: The untraveled paths [D]. Ph.D. Dissertation, Toronto: University of Toronto.

Al-Momani, I. M. 2015. Overt and Null Subject Pronouns in Jordanian Arabic [J]. Advances in Language and Literary Studies, 6(4):1-10.

Aljenaie, K. 2000. The Emergence of Tense and Agreement in Kuwaiti Arabic Children [A]. In P. Kerswill (ed.). Reading Working Papers in Linguistics [C]. 4:1-24. (https://ethos.bl.uk/OrderDetails.do?uin=uk. bl.ethos.269652)

Aljenaie, K. 2010. The Emergence of Tense and Agreement in Kuwaiti Arabic Children [J]. Journal of Child Language, 37:841-863.

Al-Sharafi, Y. 2014. The Null Subject in Modern Standard Arabic and Yemeni Arabic with Particular Reference to Tihami Yemeni Arabic [D]. Ph.D. Dissertation, Hyderabad: English and Foreign Languages University.

Al-Shawashreh, E. 2016. Aspects of Grammatical Variation in Jordanian Arabic [D]. Ph.D. Dissertation, Ottawa: University of Ottawa.

Aoun, J. E., L. Choueiri \& E. Benmamoun. 2010. The Syntax of Arabic [M]. Cambridge: Cambridge University Press.

Azim, M. 2006. Essential Arabic Syntax [D]. Ph.D. Dissertation, Hyderabad: English and Foreign Languages University.

Behrens, H. 1993. Temporal Reference in German Child Language [D]. Ph.D. Dissertation, Amsterdam: University of Amsterdam.

Benmamoun, A. 1994. The Conditions on Pro and the ECP [A]. In R. Aranovich, et al. (eds.). The Proceedings of the Thirteen West Coast Conference on Formal Linguistics [C]. Stanford: Center of the Study of Language and Information, 173-188.

Benmamoun, E. 2000. The Feature Structure of Functional Categories: A comparative study of Arabic dialects [M]. New York: New York Press.

Bel, A. 2003. The Syntax of Subjects in the Acquisition of Spanish and Catalan [J]. Probus: International journal of Latin and Romance Linguistics, 15 (81):1-26.

Borer, H. 1986. I-subject [J]. Linguistic Inquiry, 17 (3):375-416.

Borer, H. 1989. Anaphoric AGR [A]. In O. A. Jaeggli \& K. J. Safir. (eds.). The Null Subject Parameter [C]. Dordrecht: Kluwer Academy, 69-110.

Casanova, L. 1999. El Sujeto en el Catalán Coloquial [J]. Revista Española de Lingüistica, 29(1):105-131.

Casielles, E., J. Andruski, S. Kim, G. Nathan \& R. Work. 2006. Syntactic and Discourse Features of Subjects in Child Spanish: Evidence from Spanish/English bilingual acquisition [A]. In Proceedings of the 30th Boston University Conference on Language Development [C]. Somerville, MA.: Cascadilla Press, $72-83$.

Chomsky, N. 1982. Some Concepts and Consequences of the Theory of Government and Binding [M]. Linguistic Inquiry Monograph 6. Cambridge, MA: MIT Press.

Eid, M. 1993. Negation and Predicate Heads in Arabic [A]. In M. Eid \& G. Iverson. (eds.). Principles and 


\section{Fawaz Ali Ahmed Qasem}

Predication: The Analysis of Natural Language [C]. Paper in honor of Gerald Sanders. Current Issues in Linguistic Theory. Amsterdam and Philadelphia: John Benjamins, 98, 135-152.

Farghaly. A. 1982. Subject Pronoun Deletion Rule in Egyptian Arabic [A]. In S. Gamal \& R. Bower. (eds.). Discorse Analysis: Theory and application proceedings of the second national symposium on linguistics and English language teaching [C]. Cairo: Center for Developing English Language Teaching, Ain Shams University, 60-69.

Fassi-Fehri, A. 1993. Issues in the Structure of Arabic Clauses and Words [M]. Dordrecht: Kluwer.

Grinstead, J. A. R. 1998. Subjects, Sentential Negation and Imperatives in Child Spanish and Catalan [D]. Ph.D. Dissertation, Los Angeles: UCLA.

Grinstead, J. A. R. 2000. Tense, Number and Nominative Case Assignment in Child Catalan and Spanish [J]. Journal of Child Language, 27(1):119-155.

Harbert, W. \& M. Bahloul. 2002. Postverbal Subjects in Arabic and the Theory of Agreement [A]. In J. Ouhalla \& U. Shlonsky (eds.). Themes in Arabic and Hebrew Syntax [C]. Netherlands: Kluwer Academic publishers, 45-70

Haegeman, L. 1995. Root Infinitives, Tense, and Truncated Structures in Dutch [J]. Language Acquisition, 4(3):205-255.

Haegeman, L. 1996. Root Infinitives, Clitics and Truncated Structures [A]. In H. Clahsen (ed.). Generative Perspectives on Language Acquisition [C]. Amsterdam and Philadelphia: John Benjamins, 271-308.

Hoekstra, T. \& N. Hyams. 1998. Aspects of Root Infinitives [J]. Lingua, 106(1):81-112.

Holmberg, A. 2010. Null Subject Parameters [A]. In T. Biberauer, A. Holmberg \& I. Roberts (eds.). Parametric Variation: Null subjects in minimalist theory [C]. Cambridge: Cambridge University Press, 88-124.

Hyams, N. 1986. Language Acquisition and the Theory of Parameters [M]. Dordrecht: D. Reidel Publishing Company.

Hyams, N. 1989. The Null Subject Parameter in Language Acquisition [A]. In O. A. Jaeggli \& K. J. Safir (eds.). The Null Subject Parameter [C]. Dordrecht: Kluwer, 215-238.

Hyams, N. 1996. The Underspecification of Functional Categories in Early Grammar [J]. Language Acquisition and Language Disorders, 14:91-128.

Hyams, N. 2005. Child Non-finite Clauses and the Mood-Aspect Connection: Evidence from child Greek [A]. In P. Kempchinsky \& R. Slabakova (eds.). Aspectual Inquiries [C]. Dordrecht: Kluwer Academic Publishers, 293-315

Hyams, N. \& K. Wexler. 1993. On the Grammatical Basis of Null Subjects in Child Language [J]. Linguistic Inquiry, 24:421-459.

Jelinek, E. 1983. Person-subject Marking in AUX in Egyptian Arabic [A]. In F. Heny \& B. Richards. (eds.). Linguistic Categories: Auxiliaries and related puzzles [C]. Dordrecht: D. Reidel Publishing Company, 21-46.

Jelinek, E. 2002. Agreement, Clitics and Focus in Egyptian Arabic [A]. In J. Ouhalla \& U. Shlonsky (eds.). Themes in Arabic and Hebrew Syntax [C]. Dordrecht: Kluwer Academic, 71-105.

Klepper-Pang, A. 2003. Optional Structures in the Acquisition of Polish: A cross-linguistic perspective [D]. Ph.D. Dissertation, Stuttgart: University of Stuttgart.

Krämer, I. 1993. The Licensing of Subjects in Early Child Language [OL]. MIT Working Papers in Linguistics, 19:197-212. (https://www.researchgate.net/publication/247924305)

Lorusso, P., C. Caprin \& M. T. Guasti. 2005. Overt Subject Distribution in Early Italian Children [A]. In A. Brugos, M. R. Clark-Cotton, S. Ha (eds.), BUCLD 29 Online Proceedings Supplement [C]. (http://www.bu.edu/bucld/proceedings/supplement/vol29)

MacWhinney, B. 1995. The CHILDES Project: Tools for analyzing talk (2nd edition) [M]. Mahwah, NJ: Lawrence Erlbaum Associates.

Mohammed, M. A. 1988. Nominative Case, I-subjects, and Subject-verb Agreement [A]. In D. Brentari et al. (eds.). CLS [C]. Chicago: Chicago Linguistic Society, 223-235.

Phillips, C. 1995. Syntax at Age Two. Cross Linguistic Differences [OL]. MIT Working Papers in Linguistics, 26:325-382. (https://www.researchgate.net/publication/232837925) 


\section{The Acquisition Phenomenon of Null and Overt Subjects in the Early Speech of Arabic-Speaking Children}

Qasem, F. 2014. The Acquisition of Yemeni Ibbi Arabic: The development of verbal morphology and overt subject realization [D]. Ph.D. Dissertation, Hyderabad: English and Foreign Languages University.

Qasem, F. 2019. The Strong Continuity Hypothesis: Evidence from Arabic-speaking children data [J]. Macrolinguistics, 7(2):48-71.

Qasem, F. \& S. Sircar. 2017. Imperative as Root Infinitive Analogue in Yemeni Ibbi Arabic: Two case studies [J]. Arab Journal of Applied Linguistics, 2(1):1-19.

Rizzi, L. 1982. Issues in Italian Syntax [M]. Dordrecht: Foris.

Rizzi, L. 1993/4. Some Notes on Linguistic Theory and Language Development: The case of root infinitives [J]. Language acquisition, 3(4):371-393.

Roberts, I. \& A. Holmberg. 2010. Introduction: Parameters in Minimalist Theory [A]. In T. Biberauer, A. Holmberg, I. Roberts and M. Sheehan (eds.). Parametric Variation: Null subjects in minimalist theory [C]. Cambridge: Cambridge University Press, 1-57.

Saeed, F. 2011. The Syntax of Verbal Agreement in Minimalism: Formal feature valuation in English and Standard Arabic [D]. Ph.D. Dissertation, Hyderabad: English and Foreign Languages University.

Salustri, M. \& N. Hyams. 2003. Is There an Analogue to the RI Stage in the Null Subject Languages [A]. In Proceedings of the Annual BUCLD 27 [C]. Sommerville, MA: Cascadilla Press, 692-703.

Salustri, M. \& N. Hyams. 2006. Looking for the Universal Core of the RI Stage [A]. In V. Torrens \& L. Escobar (eds.). Language Acquisition and Language Disorders [C]. Amsterdam: John Benjamins, 159-182.

Sans, Y. C. \& A. Gavarró. 2006. Subject Distribution and Verb Classes in Child Catalan [OL]. (www.bu.edu/bucld/files/2013/07/2012-handbook-web-version.pdf)

Soltan, U. 2007. On Formal Feature Licensing in Minimalism: Aspects of Standard Arabic morphosyntax [D]. Ph.D. Dissertation, College Park: University of Maryland.

Villa-Garcia, J. 2011. Acquisitional Evidence Bearing on the Account of Preverbal and Postverbal Subjects in Spanish [A]. In Selected Proceedings of the 13th Hispanic Linguistics Symposium [C]. Somerville, Mass.: Cascadilla Press, 178-189. 